\title{
DISCUSSION
}

\section{THE VIETNAM SYNDROME IN FORREST GUMP MOVIE SCRIPT}

\author{
Trinh Thi Van*, Nguyen Hong Van, Nguyen Thi Thu Phuc \\ Department of Foreign Languages, \\ Hanoi University of Mining and Geology \\ Duc Thang, Bac Tu Liem, Hanoi, Vietnam \\ Received 15 March 2019 \\ Revised 16 September 2019; Accepted 22 December 2019
}

\begin{abstract}
Considered the most controversial war in the $20^{\text {th }}$ century, the Vietnam War deeply divides the American society. Especially, it causes the Vietnam Syndrome which still is an obsession of American people until today. The research is carried out on a movie script of one of the most famous Hollywood films about the Vietnam War, Forrest Gump. The collected data are analyzed on the basis of Fairclough's threedimensional framework for critical discourse analysis (CDA). The study aims to reveal the different aspects of the syndrome considered as a psychological trauma expressing in many factors such as the topic, the plot, the characters, the setting, the genre, the theme songs, and the language of the whole movie. Moreover, the movie script exposes a long period of problematic and tragic time in the history of the United States.
\end{abstract}

Keywords: critical discourse analysis, Vietnam Syndrome, movie script, Vietnam War, American Studies

\section{Introduction}

The term Vietnam Syndrome, or PostTraumatic Stress Disorder (PTSD), was first used in the early 1970 s to describe the physical and psychological symptoms of veterans coming back from the Vietnam War. By the end of the 1970s, the Vietnam Syndrome was no longer a purely medical term, and it came to have a political meaning, coined by Henry Kissinger and popularized by Ronald Reagan to describe the US's reluctance to send troops into combat situations overseas. This happened because the US was afraid that they would get bogged down in a quagmire again, like they did in Vietnam, and this would lead to a loss of support for the government.

The Vietnam Syndrome also led to

\footnotetext{
${ }^{*}$ Corresponding author. Tel.: 84-982853935

Email: trinhvan86nb@gmail.com
}

many problems in American society and people. In other words, it was a trouble of the whole country. Many veterans coming back from Vietnam have failed in efforts to have an ordinary life. More Vietnam veterans committed suicide due to psychological problems after the war than those who had died during the war. At least three-quarters in a million veterans became homeless or jobless.

Intrinsically, the Vietnam Syndrome is a collective psychological sickness caused by the conflicts between ideological powers and reality. By ideological powers we mean the belief in the "Noble" American Values, Dreams, Just Cause, Strength, etc. These powers decide the way they speak, live, and behave in their life. (Remember Thomas Paine's statement that the cause of the 
Americans is the cause of humanity). The reality is what they see: the American soldiers went to Vietnam to become "baby killers", drop napalm, and cause bloody massacres.

The question is whether the American government continually tell lies to their nation in committing all these awful actions that generate psychological disorders in the whole country while and after the war.

The demonstrations of the Vietnam Syndrome are different, but the essential is the doubt and disbelief of American people in the so-called American values. They raise questions such as: Is America really such a free and great country? Does the American Army go to Vietnam to liberate miserable people from the communists' suppression? Does the merciful God exist as they used to think? In general, it is their disillusion in the future and in life. They lose their direction to the future and do not know how to move on.

To find out the fact that the syndrome appears everywhere in every field of American society including in artworks, literature, newspapers, especially in movies; the research investigates the movie script of Forrest Gump - a very gripping example in which the Vietnam Syndrome hiddenly exists in outstanding factors of the movie such as the topic, the plot, the characters, the setting, the genre, the theme songs, and the language.

\section{Theoretical background and analytical framework}

\section{Theoretical background}

Emerging in the 1970s, CDA has developed strongly with its multidisciplinary approach on the analysis of ideology and power relation. It has drawn the attention of many linguists with the outstanding CDA works such as Fowler, Van Dijk, Wodak, and especially Fairclough. In Fairclough's point of view, CDA is defined as follows: "By "critical" discourse analysis, I mean discourse analysis which aims to systematically explore often opaque relationships of causality and determination between (a) discursive practices, events, and texts (b) wider social and cultural structures, relations, and processes; to investigate how such practices, events, and texts arise out of and are ideologically shaped by relations of power and struggles over power; and to explore how the opacity of these relationships between discourse and society is itself a factor securing power and hegemony" (Fairclough, 1995, p.132-133).

Fairclough's significant contribution to CDA is the development of the analytical framework which many researchers have considered a useful tool to do CDA studies so far. In fact, Fairclough gives his opinion on the actual nature of discourse and text analysis through the three-dimensional framework in Figure 1 below:

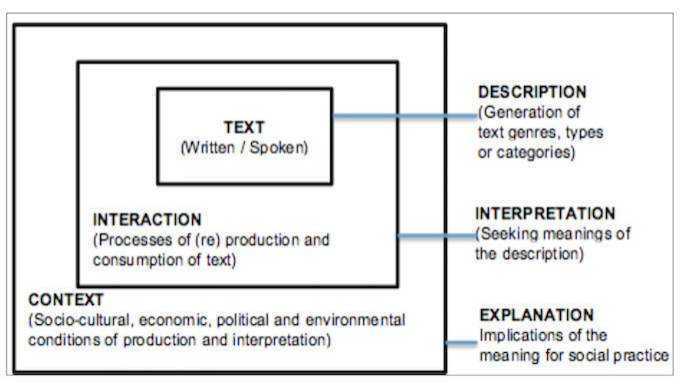

Figure 1. Three-dimension conception of discourse analysis (Fairclough, 1992)

As shown in Figure 1, Fairclough's analytical framework includes three dimensions of discourse: the text, the discourse practice, and the socio-cultural practice. Corresponding to these three dimensions of discourse, Fairclough identifies three dimensions (or stages) of CDA as follows:

Description is the stage concerned with identifying formal properties of the text. In this stage, the analysis of the language structures produced is exercised.

Interpretation is concerned with the relationship between text and interaction - 
with seeing the text as a product of a process of production, and as a resource in the process of interpretation.

Explanation is concerned with the relationship between interaction and social context - with the social determination of the processes of production and interpretation, and their social effects.

According to Fairclough's analytical framework, CDA researchers center on not just analyzing texts and the processes of their production and interpretation, but also the relationship between texts, processes, and their social conditions, both the immediate conditions of the situational context and the more remote conditions of institutional and social structures.

\section{Analytical framework}

Among a wide range of qualitative research methods, the approach of critical discourse analysis was chosen for this study in order to highlight the Vietnam Syndrome reflected in all the factors of he movie script.

The data analysis focusing on the Vietnam Syndrome based on Fairclough 's analytical framework follows a three-stage process: description, interpretation, and explanation.

In the stage of description, the authors will particularly center on the factors that constitute the movie script such as the topic, the plot, the characters, the setting, the genre, the theme songs, and the language used in the script. In the stage of interpretation, the researchers will show how the expressions should be interpreted in the specific context of the movie script of which the syndrome displays explicitly and implicitly. In the stage of explanation, the researchers will demonstrate how those expressions are affected by socio-cultural powers such as situational, social, or institutional, in this case by the Vietnam Syndrome.

The data related to chosen factors were described, and then interpreted separately.
And always independently, based on the social and historical context of the Vietnam War and American society at that time, the explanation of the data was performed in order to find out the Vietnam Syndrome hidden behind.

\section{Data analysis}

In this study, the researcher collected the data from the script of the film Forrest Gump written by Eric Roth and based on a novel by Winston Groom. The impacts of the Vietnam Syndrome on the movie script were discovered and demonstrated by analyzing the data concerning main factors of the movie such as the topic, the plot, the characters, the setting, the genre, the theme songs, and the language. Besides, some inter-textual factors, such as historical, socio-cultural, and artistic events and works, were also studied when needed.

\subsection{Topic, Plot and Characters}

\section{Topic}

The topic of the movie, is about the Vietnam War which ended many years ago. By the time the movie was created, there had already been many films, books, documentaries, articles, etc. referring to the war throughout the United States and all over the world. However, the director still chose this topic, which indicates that the questions about the war never come to an end in Americans' conception. They are always urged to go and find out the ways to solve the problems of American society as the effects of the war. It means that the Vietnam Syndrome still persists - it can hardly ever fade away from American history.

It is also fundamental to note that the war has different names in Vietnam and in the US. In Vietnam it is cuộc kháng chiến chống Mỹ cứu nước (literally an Anti-American Resistance War for National Salvation), while in the US, it is called the Vietnam War, which implies that it is just a war among other wars - and "victories" - in the US history. It is clear how the ideological powers form the names and concepts of wars in the US. 


\section{T.T. Van, N.H. Van, N.T.T. Phuc/ VNU Journal of Foreign Studies, Vol.35, No.6 (2019) 135-145}

\section{Plot}

The movie Forrest Gump follows the life events of a man who shares the name with the title of the film. Forrest faces many tribulations throughout his life, but he never lets any of them interfere with his happiness. From wearing braces on his legs to having a below average IQ and even being shot, Forrest continues to believe that good things will happen and goes after his dreams. When several unlucky things occur during Forrest's life, he manages to turn each setback into something good for him. For example, when he finally gets his braces off he discovers that he is capable of running faster than most other people. This skill allows Forrest not only to escape his bullies while he is a child in Greenbow, but also to gain a football scholarship, save many soldiers' lives and become famous for his ability. While Gump eventually achieves the majority of the things he hoped to throughout the movie, it proved a much more difficult task to win the heart of his life-long friend Jenny Curran.

The movie centers on Forrest Gump who is always called an idiot or a stupid man throughout the film, and the incidents that occur during his life. Interestingly, Forrest's life journeys take place at the same time as the Vietnam War (1955-1975). Therefore, the questions he asks himself about his life appear to be the questions of Americans about the war.

The image of Forrest Gump symbolizes that of the United States during the Vietnam War. America is considered to behave like an idiot in the conflict. In the end, they do not know how to move on or how to leave it. The Vietnam War is forever a black eye in American history.

\section{Characters}

As mentioned above in the plot, the film focuses on life journeys of the main character Forrest Gump who shares the same name as the title of the movie. He was named after a soldier in the American Civil War (18611865).
When I was a baby, Momma named me after the great Civil War hero, General Nathan Bedford Forrest.

General Nathan Bedford Forrest is also the person who starts up the club called $\mathrm{Ku}$ Klux Klan. "They'd all dressed up in their robes and their bed sheets and act like a bunch of ghosts or spooks or something". It seems to be one way that the director uses to recall the Vietnam War. Behind that is the presence of the Vietnam Syndrome expressed in the film.

There are three other major characters of the movie who stick to Forrest's life. They are Jenny, Lieutenant Dan Tayler (Lt. Dan) and Bubba. Jenny is Forrest's childhood friend whom he immediately falls in love with and never stops loving throughout his life. Being a victim of child sexual abuse at the hands of her bitterly widowed father, Jenny embarks on a different path from Forrest, leading a self-destructive life and becoming part of the hippie movement in the 1960s and the 1970s drug culture. She takes part in the antiVietnam war protests, and travels all around the country with strangers. She dies at the end of the movie.

Lt. Dan is Forrest and Bubba's platoon leader during the Vietnam War, whose ancestors have died in every American war, and he regards it as his destiny to do the same. After losing his legs in an ambush and being rescued against his will by Forrest, he is initially bitter and antagonistic towards Forrest for leaving him a "cripple", and as a result, he falls into a deep depression.

Bubba is Forrest's friend whom he meets upon joining the Army. Bubba was originally supposed to be the senior partner in the Bubba Gump Shrimp Company, but he dies by a river in Vietnam.

It can be seen from the main characters of the movie that all their lives are destroyed in one or another way by or during the time of the Vietnam War. They either die or become disabled because of the war.

These characters seem to embody the image of the United States at that time, 
completely ruined and bitterly divided - a disabled America.

\subsection{Setting and genre}

\section{Setting}

The film is set mainly in the city of Savannah, Georgia where the main character, Forrest Gump, sits on a bench to tell a story about his life. The question is why did the director choose Georgia, not other states to be the setting of the movie?

In fact, Georgia joined the Confederacy and became a major theater of the Civil War (1861-1865) in the early 1861. It was the state where main battles took place from Atlanta to Savannah. A lot of Georgian soldiers die in service, roughly one of every five who served. Georgia also became the last Confederate state to be restored to the Union. One more noticeable fact, Georgia is a state which is split many times. From 1802 to 1804, western Georgia was split to the Mississippi Territory, and later was split to form Alabama with part of former West Florida in 1819. Moreover, it is one of the states in the USA where racism happens prominently. In 1908, the state established a white primary with the only competitive contest within the Democratic Party, which was another way to exclude blacks from politics.

Additionally, $\mathrm{Ku}$ Klux Klan, an American terrorist organization which advocated extremist reactionary positions such as white supremacy, white nationalism, and anti-immigration developed quickly and successfully in Georgia with the foundation of the Association of Georgia Klans.

With all these important and complicated facts about the state of Georgia, can we conclude that the director of the movie has reasons for his choice? He probably intentionally chose a place where people were divided for a long time in the war of their own nation.

Is it the same as the Vietnam War, which is believed to traumatize and divide the American people for decades, and do immense harm to the image of the United States in the world?

\section{Genre}

The genre of Forrest Gump is a drama but mixing with a comedy.

The movie seems to be an epic, but that is an epic about an American citizen with a low IQ of 75 who is often considered a local idiot. However, he is a hero in the war because of rescuing his teammates from a bomb explosion and attack of the enemy by running. Formally, Forrest is " a football star, and a war hero, and a national celebrity, and a shrimp boat captain, and a college graduate, the city offathers of Greenbow, Alabama."

On the other hand, all the events in his life are funny and foolish. For example, when he was put in the All-America Team and invited to meet the President of the United States in the Oval Office, he just cares about food and drink. "The real good thing about meeting the President of the United States is the food". He drank about fifteen Dr. Peppers. When President Kennedy shakes his hand and asks "How do you feel?", he replies "I gotta pee".

Another time Forrest comes again to get the Medal of Honor from the President of the United States, he drops his pants, bends over and shows the bullet wound on his bare buttocks to President Johnson. All these ridiculous actions appear not to occur accidentally in his life, but it seems to be an anti-power against all the American values such as wealth, freedom, or nobility.

Forrest's behaviors sound to reflect the American society at that time. According to public media, America is a wonderland, a land of freedom and democracy; but in fact, it is a place where racism, inequality, discrimination, etc. happen in every corner of the society.

\subsection{Language}

The language used by the characters in the movie is very diverse. Especially the offensive language appears densely under words or phrases in the whole script. The character who used such kind of language the 
most is Lt. Dan. He normally adds words such as "goddammit", "shit" or "son-of-a bitch" in his speech. With the appearance of other bad words like "Viet fucking Nam", "this fucking war", "the whole damn country", or "Goddam bless America", it seems that the characters like to say that in their everyday conversation. However, the use of these curses reflects an uncomfortable attitude of American people toward the society at that time. They have to live in an unpleasant condition where discrimination, violence, and racism happen in every corner of life. They are disappointed with the government and hopeless about the future. That is one aspect of the Vienam Syndrome mentioned in the movie.

Together with those offensive words, there are many other expressions that demonstrate the syndrome presented in the film script.

When being shot in a battle field in Vietnam and breathed the last breath of his life, Bubba, an American soldier, whispered to his friend, Forrest, "Why'd this happen?". This is a rhetorical question of Bubba about his current situation: why his platoon was attacked and why he was badly wounded. It is a wonder about his injury; it sounds, however, to be a bitter question why this war happened and why America got involved into this war. For many years during the Vietnam War and after it ended, American people have still gone to find the answers to the questions how the war began, why it bred so much dissent, or why it lasted so long. The question of Bubba reminds us of a great song named "I feel like I'm fixing a die rag" written by Country Joe McDonald (1967).

And it's one, two, three

What are we fighting for?

Don't ask me, I don't give a damn

Next stop is Vietnam

And it's five, six, seven

Open up the pearly gates.

Well there ain't no time to wonder why

Whoopee! We're all gonna die

The song is about placing the blame on American politicians, high-level military officers, and industry corporations for starting the Vietnam War. "What are we fighting for?" is the question which young Americans drafted for the Army always attempt to get the answer.

After being badly injured, Bubba said something to Forrest that he never forgets: "I wanna go home." That is the last wish of a soldier when he got shot at a distance very far from his hometown. He wanted to go home with his mom and his family all around. It is very sad that his dream never comes true. He died right there by that river in Vietnam. The hope of Bubba appears to be an echo of a slogan of protests against the Vietnam War that spreads on all the streets of America from the late 1960 s to the early 1970 s, "Bring them home". "Bring them home" or "Bring the boys home" are catchwords aimed at the sending of troops to fight in a war considered increasingly unpopular in the United States. The slogan is also the name of a famous anti-war song written by Pete Seeger in 1971.

For defense you need common sense

Bring them home, bring them home

They don't have the right armaments

Bring them home, bring them home.

The song is an anti-war anthem emphasizing the fact that American government should pull their military out of Vietnam.

Another expression deeply indicates the Vietnam Syndrome is that of Lt. Dan. When he was badly injured in the battle field, Forrest ran to rescue him, after that he was taken to the hospital and survived. Later on, he got very angry with Forrest and shouted at him: "Did you hear what I said. You cheated me. I had a destiny. I was supposed to die in the field. With honor! That was my destiny! And you cheated me out of it!"

In fact, he was rescued by Forrest, and Forrest did not cheat him anything, but he repeatedly said that Forrest cheated him. So who cheated Lt. Dan? It appears that "you" here is the American government. It was the 
United States' Presidents who cheated all the soldiers to go to Vietnam to fight an unjust war. They said to the soldiers to come to Vietnam to stop the communist in order to liberate the miserable people there. They thought they came to do a noble job in their life, but the truth is very different. They came to Vietnam to kill women and children, to do terrible work that they had not expected before. At that time, they bitterly realized that they were cheated by their own top leaders.

At a later time, Lt. Dan became "a legless freak", and he did not know what to do with the rest of his life. He screamed: "What am I gonna do now? What am I gonna do now?". The impasse of Lt. Dan's situation after being amputated is also the deadlock of the whole American society succeeding many years of involvement into the war. The US Army could not stay, and could not leave. They do not know how to escape from the mud. This makes us think of another well-known song of Pete Seeger "Waist deep in the big muddy" written in 1967.

We were waist deep in the Big Muddy.

And the big fool said to push on.

The song was considered symbolic of the Vietnam War (the Big Muddy) and President Lyndon Johnson (the big fool) 's policy of escalation, then widely seen as pushing the United States deeper into the increasingly unpopular war.

In the expression above, the repetation of the rhetorical question of Lt. Dan remains engraved on Americans' minds about an unforgetable memory of a horrible period of time. It is like a startled saying of the whole American society. The US got involved in a war on the other side of the world for very poorly justified reasons. They did not really know how to win, or even have a definition of winning, and they used all the military power they had (except nuclear weapons) to commit massive human right violations against the population of a poor third world country, and yet they achieved precisely nothing.
In another situation when Forrest went to Washington, DC to receive the Medal of Honor from the President of the United States, he was put in a line with the other veterans against the war, and asked to tell the crowds about the war in Vietnam. When Forrest was about to speak, there was a policeman pulling the patch cords out of the audio board, so that people could not hear anything. "We can't hear you. We can't hear anything." The only thing that people can hear is the last sentence in Forrest's speech: "That's all I have to say about that." The image of a veteran continuing to speak into the microphone without any sound seems to symbolize the whole nation who cannot speak out the truth. They have no chance to know about what American soldiers think and do in Vietnam. They really want to know the truth, but the only thing they can hear from the government is nothing at all. All people in the country have no opportunity to raise their voice and to understand what is happening in the war. The American government always finds the way to cover the truth. Therefore, the American people do not know the true story behind the mask.

The Vietnam War causes the entire American society a disbelief in noble values considered the symbol of the United States. Even though about $70 \%$ of American population follows Christianity, they have to question about their religious belief after the war. They doubt whether there is Jesus Christ existing in this world. This is clearly indicated in Lt. Dan's speech when he talks to Forrest years later upon their re-union.

Have you found Jesus yet, Gump? Jesus this and Jesus that. Have I found Jesus? They even had a priest come and talk to me. He said God is listening, but I have to help myself. Now, if I accept Jesus into my heart, I'll get to walk beside him in the Kingdom of Heaven. 


\section{T.T. Van, N.H. Van, N.T.T. Phuc/ VNU Journal of Foreign Studies, Vol.35, No.6 (2019) 135-145}

Did you hear what I said? Walk beside him in the Kingdom of Heaven. Well, kiss my crippled ass. God is listening. What a crock of shit!

His words prove the hopelessness of Americans to the merciful God. They no longer believe in what they often pray in the church that Great Jesus would give them peace and a better life. The world they are living in is full of loss and depression. The repetition of the word "Jesus" or "God" in Lt. Dan's speech exposes the bitter despair of an amputated veteran who has nothing to lose as well as nothing to live by.

The loss of his life also is demonstrated in the conversation between him and two prostitutes when they argue with each other at New Year's night. The prostitutes repeatedly call him "You big loser!", "You retard!", "You freak!", or "You so pathetic!" All these imperative sentences, like a needle, stab into his heart and make his life more tragic. He is not only a loser in the war, but also a loser in his life. Coming back from Vietnam and being a crippled veteran, Lt. Dan has to stay in a hotel and "lives off the government tit". He totally no longer believes in anything in this world. As Forrest said "there's something you can't change." He cannot change the truth that he is now a legless freak. His life is destroyed by the Vietnam War. Appallingly, it is the same as the United States that is deeply divided by the war. The war is over and reveals an America which is full of people with disabled minds.

One of the most important expressions that appears in the script is the question that people often ask Forrest at the first time they meet him: "Are you stupid or something?" Forrest is a simple-minded man with a low IQ of 75 , so he usually behaves very differently from what people often think. Therefore, the question is directly about Forrest's intelligence. Whenever he performs strangely, people ask him that question. However, the interrogative sentence probably veils another meaning which seems to be related to the performance of the United States in the Vietnam War. Is Forrest stupid or America itself a big idiot?

\subsection{Theme songs}

Many anti-Vietnam war songs written in the 1960s and the 1970s are used in the movie script. "Blowing in the wind" (1962) is one of the best songs of all time performed by the character Jenny in the film.

How many roads must a man walk down before you call him a man?

How many seas must a white dove sail

before she sleeps in the sand?

Yes, and how many times must the

cannon balls fly

before they're forever banned?

The song was written by Bob Dylan during the early sixties which was right when the United States started sending more troops into Vietnam. It poses a series of rhetorical questions about peace, war, and freedom. This is an anti-war song that does not only make a specific reference to the Vietnam War but was also written to make people view the wars in a negative way. Dylan uses lots of rhetorical questions that are meant to criticize the country's involvement in wars, specifically the one in Vietnam.

Another song, "Fortunate Son" (1969), is one of the Vietnam era's best-known protest songs.

Some folks are born made to wave the flag.

Ooh, they're red, white and blue.

And when the band plays "Hail to the Chief,"

ohh, they point the cannon at you all.

It ain't me. It ain't me.

I ain't no Senator's son, no.

It ain't me. It ain't me...

Written by John Fogerty and performed by Fogerty's band, Creedence Clearwater Revival, Fortunate Son takes aim at the United States' political and military elite the men who push for the war but are seldom affected by it. According to Fogerty, Fortunate 
Son was inspired by the marriage of Dwight D. Eisenhower's grandson to Richard Nixon's daughter. In simple but angry tones, Fogerty's lyrics suggest that the children of the working classes - not "senator's sons" or "millionaire's sons" - are drafted and sent into the teeth of war. "It ain't me. It ain 't me. I ain 't no Senator's son, no. It ain 't me. It ain 't me...". This indicates that the only fortunate or lucky ones in the war are soldiers who can get themselves out of the army or out of the military by having special relations with people inside the government. The song, released during the peak period of the US's involvement in Vietnam, is not explicitly a criticism of that war in particular, but it also "speaks more about the unfairness of class than war itself," according to its author, John Fogerty. "It's the old saying about rich men making war and poor men having to fight them."

The third example, "For what it worth" (1967) is a well-known protest song written by Stephen Stills and performed by Buffalo Springfield.

There's something happenin' here.

What it is ain't exactly clear.

There's a man with a gun over there, telling me I got to beware.

The song was written during the Vietnam War when America was split between anti-war protesters and pro-war civilians. The group tried to use this song to make people realize the actual actions that the war was causing and base their opinion on the events.

There are some other songs mentioned in the film such as "Mr. President (have pity on the working man)" (1974), "Where have all the flowers gone?" (Pete Seeger, 1961) or "All along the watchtower" (Bob Dylan, 1967). All these songs play an important cultural role during the Vietnam War. Great arts are often produced in the hardest time, and some of the most iconic music genres of the 20th century were produced during the 1960s and early 1970s in protest of America's involvement in the Vietnam War. Artists like Bob Dylan, Pete Seeger or Randy Newman speak out against the war by their greatest protest songs ever.

\subsection{Symbol of the running man}

The movie Forrest Gump shows historical events that took place from the 1950s through the 1970s out of the perspective of a mentally underdeveloped person - Forrest Gump - the main character. There are no explanations given why things happen, but occasionally Forrest offers his own explanations, which seem stupid to the spectator, but are understandable, because the viewer is constantly reminded of Forrest's low IQ. Within the storyline, many metaphors are used. They animate the audiences to think more deeply about events and question why things happen the way they do. One of them is that throughout the movie Forrest is constantly "on the run". So why is he running? And what are the makers of the film trying to say by using this metaphor?

The first time he ran was in Forrest's childhood years when he walked down a street together with Jenny and was attacked by a group of kids. They threw stones at him and called him names. Forrest obviously did not know how to react and just stood still as if he was paralyzed, waiting for what would happen next. Jenny gave him a solution by telling him to run away. Forrest started running and escaped from the kids. Through this incident, he noticed for the first time that running away was a good solution to get out of dangerous situations.

The second time when he is already in college, he is again running away from men chasing him and by accident he gets on a football field. He is seen by the coach of the team and gets immediately drafted as a player. He does not know the rules of the game. And he does not need to, because his whole job consists of catching the ball, running towards the enemy line and hitting a home run. One can see that Forrest does not know what he is doing by the huge posters shown which are supposed to guide him. They read, "Go Forrest", and "Stop Forrest". On the stands, people form letters saying "Go Forrest". He becomes a successful football player. And he notices again that he can be successful by simply running. 
Before Forrest has to leave for the Vietnam War, Jenny tells him to run and not to be brave whenever he is in danger. One day his platoon gets caught in a shooting and he runs away and thus gets away from getting shot. He is the only not-badly injured person in his platoon and rescues many of his mates.

There are many other times when Forrest just runs. After his mom's death, Forrest runs across the United States, gets national media coverage, and by the way "invents" the bumper sticker Shit Happens and the Smiley face.

These are only the main examples of Forrest running in the movie. Every time Forrest runs, he gets away from a dangerous or unfortunate situation and ends up turning it into earning success and glory for himself. He does not realize himself what he is doing or why he is doing it, but it works out every time. This metaphor presumably symbolizes the insecurity of the common people living at that time, the "baby boom generation". People live their lives without knowing what is happening around them and why it is happening. They have no active influence on the events surrounding them.

Furthermore, there is another underlying meaning of Forrest's running. For many years, the US government got bogged down to the war in Vietnam throughout five presidents, especially from Lyndon B. Johnson to Richard Nixon. At the beginning of 1970s, Nixon tried to find out the way to withdraw his army from Vietnam in honor, but no way of putting the war to an end. The character's running appears to convey a lot of underlying meanings. The dynamic verb "run" is totally mentioned about 102 times in the whole movie script. It seems to be the symbol of the US Army's running away from the Vietnam War. They run away after a long time of being deep inside the hell without the way to escape. American soldiers in Vietnam and American people in the United States completely lose their beliefs in a victory of the country. When the truth about what the US soldiers do in Vietnam is gradually brought to light, they no longer believe in the promises of the government that they will soon end up the war. After Tet Offensive (1968), the US government realizes the dead-end destiny and tries to find out the solution for getting out of their tragic situation in Indochina. They try to run away as Forrest does in the film. Running away is to escape from a really horrible tragedy in Vietnam.

Additionally, Forrest's running comes across to imply another meaning - an escape from the obsession of the Vietnam War years after the war. Perhaps, there is no other conflict that makes American people get into such a panic. Therefore, they run to flee away the past as it means in Forrest's saying, "My Momma always said you got to put the past behind you before you can move on. And I think that's what my running was all about'. The Vietnam War was, and still is, an important part of the lives of many Americans. It is the Vietnam Syndrome that still haunts their heart and mind many years after the war.

\section{Conclusion}

The underlying reasons for the Vietnam Syndrome are the conflicts between the ideological myth of American noble values such as freedom, equality, human rights, etc. and what badly happened in the Vietnam War - killing babies and women, inequality, and racism were practiced by American soldiers. Thomas Paine, one of the greatest fighters of freedom and independence in American history claimed in his famous book Common Sense (1776) that "The cause of America is in a great measure the cause of all mankind". But what the US Army did in the war made their people bitterly disappointed and disbelieved in the government. It led to the psychological trauma in the whole American society. In other words, they asserted that the ideal wonderland has already gone.

Our analysis shows that the Vietnam Syndrome is obsessive in the whole Forrest Gump script. It strongly influences the topic, the plot, the characters, the setting, the genre, 
the theme songs of the film, and the language used in the movie.

The study is an attempt to apply CDA approach to an artistic text in order to figure out the hidden messages in a movie script seen as a text produced in a historical and social context with a specific situation. Our work shows that to understand the meaning of a discourse, it is very important for teachers and learners to find out not only its textual, but also the extra-textual and inter-textual factors.

\section{Acknowledgements}

We would like to express our thanks to our teacher, Dr. Ngô Tự Lập for all his help and guidance. Were it not his support, we would not have the courage to complete this research. His valuable comments and suggestions also played an important part in the finalization of this study.

\section{References}

Alan Rohn, Vietnam Syndrome, 2014. Available at https://thevietnamwar.info/vietnam-syndrome/ accessed on June 27, 2014.
Christian G. Apply (2003). Patriots: The Vietnam War remembered from all sides. New York: Viking.

Fairclough, N. (1989). Language and Power. London: Longman.

Fairclough, N. (1992). Discourse and Social Change. Cambridge: Polity Press.

Fairclough, N. (1995). Critical discourse analysis: The Critical Study of Language, London: Longman.

Fowler, R., On critical linguistics, In Caldas-Coulthard, C.R. \& Coulthard, M.(Eds) (1996). Texts and Practices: Readings in Critical Discourse Analysis. Routledge, 3-14.

Van Dijk, T.A. (1984). Pragmatics \& Beyond, Vol.3, Prejudice in Discourse, John Benjamins Publishing Company.

Van Dijk, T.A. (1993). Principles of critical discourse analysis. Discourse \& Society. Sage, 4(2), 249-83.

Van Dijk, T.A., Critical Discourse Analysis. In D. Schiffrin, D. Tannen, \& H.E. Hamilton, (Eds) (2001). The Handbook of Discourse Analysis. Oxford: Blackwell, 352-71.

Wodak, R. \& Meyer, M. (Eds), (2009). Methods of Critical Discourse Analysis ( ${ }^{\text {nd }}$ revised edition), London: Sage.

\title{
HỘI CHỨNG VIỆT NAM TRONG KỊCH BẢN PHIM FORREST GUMP
}

\author{
Trịnh Thị Vân, Nguyễn Hồng Vân, Nguyễn Thị Thu Phúc \\ Bộ môn Ngoại ngũu, Khoa Khoa học cơ bản, Trưòng Đại học Mỏ - Địa chát \\ Đức Thắng, Bắc Tù̀ Liêm, Hà Nội, Việt Nam
}

Tóm tắt: Sự sụp đổ của chính quyền Sài Gòn vào ngày 30 tháng 04 năm 1975 đã đánh dấu sự chấm dứt của cuộc chiến tranh Việt Nam kéo dài trong suốt 20 năm. Được coi là một trong những xung đột gây tranh cãi nhiều nhất của thế kỉ 20, cuộc chiến tranh Việt Nam đã phân chia sâu sắc xã hội và con người Mỹ. Đặc biệt, cuộc chiến còn gây ra Hội chứng Việt Nam mà đến ngày nay vẫn còn là nỗi ám ảnh của toàn nước Mỹ. Nghiên cứu này được thực hiện trên kịch bản của bộ phim Forrest Gump - một trong số những bộ phim nổi tiếng và thành công nhất của điện ảnh Hollywood về đề tài chiến tranh Việt Nam. Dữ liệu được phân tích dựa trên khung lí thuyết ba lớp của nhà ngôn ngữ học người Thụy Sỹ Norman Fairclough. Kết quả nghiên cứu đã chỉ ra những khía cạnh khác nhau của hội chứng Việt Nam - ẩn sâu là một chấn thương tâm lí của người Mỹ - được diễn tả trong nhiều yếu tố của kịch bản phim, điển hình đó là chủ đề, cốt truyện, nhân vật, bối cảnh, thể loại, nhạc nền, và ngôn ngữ được sử dụng trong bộ phim. Hơn thế nữa, kịch bản bộ phim còn phơi bày một giai đoạn lịch sử đầy bi kịch của nước Mỹ.

Tù khóa: phân tích diễn ngôn phê phán, hội chứng Việt Nam, kịch bản phim, chiến tranh Việt Nam, Hoa Kỳ học 